PIOTR ZBRÓG

ORCID: 0000-0002-9512-4027

Uniwersytet Jana Kochanowskiego w Kielcach

\title{
Początki kształtowania się reprezentacji społecznej zapożyczeń w sferze publicznej
}

\section{Wstęp}

Celem niniejszego artykułu jest opis procesu powstawania reprezentacji społecznej zapożyczeń, zapoczątkowanego w szesnastowiecznej sferze publicznej. Obserwacje i analizy werbalizacji uczestników ówczesnego dyskursu pozwoliły do pewnego stopnia zrekonstruować sposób ówczesnego ich postrzegania w wymiarze deskryptywnym i afektywnym oraz ukazać dynamikę przemian wraz z czynnikami je determinującymi.

Zapożyczenia, czyli „obce w strukturze danego języka wyrazy, zwroty, typy derywatów, formy fleksyjne, konstrukcje składniowe, związki frazeologiczne" (Jadacka 2004: 1692), przenikały do polszczyzny już w okresie przedpiśmiennym i w ciągu wieków stale rosła ich liczba oraz zmieniały się kierunki pożyczek (por. np. Klemensiewicz 1974). Wraz z pojawianiem się elementów obcych w pewnym momencie - około XVI wieku — zaczęto odnosić się do nich w różnych tekstach, a opinie na ich temat były sprzeczne. Walery Pisarek pisał, że

ocena wyrazów obcych z punktu widzenia kultury języka narodowego nie może być jednoznaczna. Po pierwsze dlatego, że nie sposób się od nich odgrodzić, po drugie, iż zapożyczenia, godząc w czystość języka, jednocześnie istotnie wzbogacają jego zasób leksykalny, po trzecie zaś dlatego, że za każdym razem ocena zapożyczenia zależy od stopnia, w jaki jest ono uzasadnione i potrzebne. (1991: 378) 
Z tego względu warto przedstawić, jak wyglądała recepcja zapożyczeń u początków kształtowania się ich społecznego wizerunku. Podstawą metodologiczną opisu była teoria reprezentacji społecznych (dalej: TRS).

W celu ujawnienia składników reprezentacji społecznej wyrazów zapożyczonych kluczowe było ustalenie, za pomocą jakich nośników językowych kotwiczono je w tekstach, jakich ekwiwalentów używano do ich nazwania, co i w jaki sposób o nich pisano oraz jak mogło to oddziaływać na potencjalnych odbiorców tych sądów i opinii (Zbróg, Zbróg 2017). W związku z tym ekscerpcji podlegały dostępne teksty, werbalizujące zarówno wiedzę zdroworozsąadkową (potoczną, codzienną), jak i specjalistyczną z badanego okresu. Należy nadmienić, że ten pierwszy składnik okazał się najważniejszy — mieści się on bowiem w głównym nurcie zainteresowania TRS.

Biorąc pod uwagę cytowane spostrzeżenia Walerego Pisarka na temat niejednoznacznej oceny elementów obcych, nietrudno zrozumieć, że zapożyczenia wywoływały i wywołują dyskusje. W przestrzeni publicznej już od końca okresu staropolskiego pojawiały się na ich temat wypowiedzi o charakterze antagonistycznym, często konfrontatywnym, polemicznym, budujące ich sprzeczny obraz.

Analizie poddano wypowiedzi na temat zapożyczeń, które pojawiały się w sferze publicznej — tam, gdzie członkowie każdej społeczności komunikują się, wymieniają poglądy, spierają się, publikują swe wypowiedzi, gdzie opinia publiczna asymiluje jednostkowe sądy oraz aktywnie je przetwarza w toku dyskusji, w nawiązaniach i polemikach. Werbalizacje te kształtowały u odbiorców i nadawców wizerunek zapożyczeń w wymiarach opisowym oraz emocjonalnym. Przejmowanie i przyswajanie dostępnego zbioru werbalizacji związanych z elementami obcymi dokonywało się zatem w sferze publicznej, która ex definitione umożliwiała niektórym jej uczestnikom formułowanie własnych sądów i opinii oraz - zależnie od woli i pozycji — ujawnianie ich wszystkim innym. Recepcja, przetwarzanie i wysyłanie wiedzy zdroworozsądkowej kształtowały reprezentację społeczną zapożyczeń, podlegającą dalszym zmianom z powodu fluktuacji starych i nowych werbalizacji. Wyekscerpowane sądy i opinie na temat zapożyczeń przeanalizowano z wykorzystaniem kategorii reprezentacji społecznych. Ich dokładniejszej eksplikacji dokonał Serge Moscovici (m.in. 1984, 2000), tworząc podstawy TRS. Teoria ta umożliwia szczegółowe analizy nad tym, w jaki sposób członkowie społeczeństw współtworzą rozumienie ważnych dla nich zagadnień oraz problemów, wykorzystując m.in. mechanizmy zakotwiczania, obiektyfikacji i polifazję kognitywną.

Należy zwrócić uwagę, że ówczesne reprezentacje społeczne zapożyczeń konstruowano na podstawie tekstów thumaczy, drukarzy, naukowców, duchownych, ludzi kultury i polityki oraz aktywności różnych podmiotów sfery publicznej w codziennych sytuacjach komunikacyjnych. Ci członkowie społeczności formułowali pierwsze werbalizacje, stanowiące podwaliny dla wizerunku jednostek obcych - 
początkowo nieliczne, później stały się trwałym składnikiem całego zbioru wypowiedzi na temat języka polskiego. Należy dodać, że do dziś ów składnik można uznać za jeden $\mathrm{z}$ dominujących $\mathrm{w}$ dyskursie poświęconym polszczyźnie.

Ważnym argumentem za podjęciem badań nad kształtowaniem się reprezentacji zapożyczeń w okresie staropolskim okazało się ustalenie Moscoviciego (1984, 2000), że najlepszy moment na rozwijanie się, modyfikację reprezentacji społecznej wybranego obiektu stanowi pojawienie się nowej wiedzy i poglądów. Pod koniec XV i w XVI wieku zapoczątkowana została z dość istotną siłą faza uświadomienia przez Polaków doniosłej roli języka polskiego jako elementu tożsamości narodowej, w związku z czym doszły do głosu nowe sposoby postrzegania polszczyzny m.in. jako potencjalnego narzędzia komunikacji naukowej, retoryki, kazań (por. Morawski 1923; Taszycki 1953; Mayenowa 1955). Silnie zaczęto akcentować konieczność zwiększenia aktywności w zakresie tworzenia zastępników dla obcych jednostek, co wiązało się często z tworzeniem negatywnego obrazu ,cudzoziemszczyzny”. W odniesieniu do TRS ten moment należy uznać za istotny, stąd zainteresowanie tym, w jaki sposób werbalizowano $\mathrm{w}$ tekstach opinie i sądy na temat zapożyczeń. Wtedy już bowiem uaktywniła się znaczna część mechanizmów komunikacyjnych, służących temu, aby wiedzę na temat obcych elementów przekonstruować w wiedzę zdroworozsądkową, dostępną mniej świadomym przez "zakotwiczanie” polegające na „dołączaniu” czegoś nowego do czegoś już znanego (Moscovici 2000). Zjawiska, które wystąpiły od przełomu XV i XVI wieku w odniesieniu do recepcji elementów „cudzoziemskich”, szczególnie dobrze nadają się do studiowania. Ujawnily one, jak modyfikuje się stare idee oraz w jaki sposób w debacie publicznej powstają nowe reprezentacje społeczne. W tym wypadku przełomem okazały się działania podjęte w XVI wieku przez wykształcone warstwy na rzecz przemiany w dotychczasowym postrzeganiu łaciny i polszczyzny: tym „starym, pewnym” był dotychczasowy wizerunek tych języków - łacina jako nobilitująca i uczona, polszczyzna jako „prosta i uboga”, „nowym” zaś próba jego zmiany, antycypowana wcześniejszymi zdarzeniami w sferze publicznej. Powstałe nowe reprezentacje tych języków - także z kluczową rolą zapożyczeń w ich postrzeganiu — w kolejnych wiekach zmieniły diametralnie obraz łaciny (i innych obcych języków) oraz polszczyzny, a w konsekwencji także i ich społeczną rolę.

Analizom w badaniach własnych podlegały teksty drukowane w książkach, publikacjach zwartych, artykułach, listach, zapisach wypowiedzi oraz relacje z wypowiedzi. Chronologicznie badaniem objęto głównie teksty szesnastowieczne oraz w niektórych wypadkach z XVII wieku. Umożliwiło to obserwacje sposobu uzgadniania, ujawniania, przekazywania i utrwalania w sferze publicznej wybranych składników reprezentacji społecznej zapożyczeń. 


\section{Początki tworzenia się reprezentacji społecznej zapożyczeń}

Pierwsze wypowiedzi na temat zapożyczeń w szesnastowiecznej sferze publicznej pojawiały się okazjonalnie: we wstępach do przekładów, fragmentach listów, dziełach literackich, hasłach słownikowych. Tłumacze dzielili się np. swoimi refleksjami na temat trudności ze znalezieniem rodzimych odpowiedników jednostek łacińskich czy greckich, dlatego też czasem nawet zapowiadano z pewnym zawstydzeniem, że w utworze pojawią się wyrazy obce.

Zapożyczenia w polu kontekstowym nominowano wyrażeniami, w których można byłoby dostrzec neutralną próbę oznaczenia desygnatu, np.: greckie słowa, łacińskie słowa, czeskie słowa, mówiono na nie także np. słowa z łacińskiego języka i język taciński - czyli wyrazy z tego języka. Pojawiał się przejęty $\mathrm{z}$ łaciny makaronizm, także $\mathrm{w}$ wariancie stowo makaroniczne, oraz barbaryzm, także latynizmy, grecyzmy, a więc jednostki mające charakter terminów. Niektóre swoiście nacechowano mimo swego ogólnego wymiaru, np.: cudze słowa, słowa zagraniczne, słowa cudzoziemskie, cudzoziemskie terminy. W końcu czasem posługiwano się metaforycznymi zwrotami wyraźnie afektywnymi, typu: haftować tacińskimi wzorkami, haftować łacina.

Poniżej pogrupowano uogólnione sposoby werbalizowania opinii i sądów na temat jednostek obcych, składające się w konsekwencji na poznawczy i emocjonalny wymiar reprezentacji społecznych zapożyczeń.

\section{Deskryptywny wymiar reprezentacji społecznej wyra- zów zapożyczonych}

Ten aspekt ujmował istotę, cechy, przyczyny pojawiania się wyrazów obcych w tekstach, ale także - antagonistycznie - uzasadniał ich zbędność oraz trudności komunikacyjne przez nie wywoływane. Sądy miały dla odbiorców charakter poznawczy i poszerzały zakres ich wiedzy na temat zapożyczeń. Oto zasadnicze składniki tego aspektu reprezentacji w wyborze. Ze względu na ograniczenia ilościowe egzemplifikację ograniczono do minimum.

1. Zapożyczenia to elementy funkcjonalne - konieczne ze względu na małą adekwatność opisową języka polskiego.

Wykazywano, że brak stosownej rodzimej leksyki, zwłaszcza w opracowaniach naukowych, zmusza do wykorzystania w nich wyrazów cudzoziemskich. Konieczność posłużenia się terminami greckimi w narracji filozoficznej uzasadniał Marcin Kromer w przedmowie do opracowania O kościele bożym albo Krystusowym. Pisał w niej, że do tekstu: ,się nieco greckich słów a polskich niezwyczajnych wtaczało” (1553: 173). Jan Malecki przekonywał, że „bez pomocy czeskiego języka 
i czeskiego Pisma św. ani sposób dokonać przekładu Biblji na polskie, bo język polski nadmiernie jest zepsutym" (Defensio...).

Na podstawie tego typu sądów powstał składnik funkcjonalny reprezentacji zapożyczeń jako koniecznego elementu przekładu.

2. Zapożyczenia czynią tekst niezrozumiałym.

W wielu wypowiedziach opisywano konieczność podejmowania zabiegów w celu pozbycia się wyrazów z innych języków. Marcin Siennik pisał o usuwaniu zapożyczeń z tekstu nieznanego autora: „Albowiemech w jego pisaniu siła rzeczy słowiańskiej, serbskiej nalazł, której by dziesiąty przynajmniej wyrozumieć nie umiał" (1564)

Antoni Schneeberger Tigurinus (1556) zamieścił w swojej książce polskie nazwy ziół dla lepszego zrozumienia wywodu przez polskiego czytelnika.

Stanisław Solski dowodził, że od nauki geometrii odstręczają m.in. „słowa i terminy greckie i łacińskie", które on w swojej książce podał po polsku:

Imiona i nazwiska linii, angułów i figur takem akkomodował, aby nie trudniły własnego ich wyrozumienia ani pamięci nie fatygowały. I już mam doświadczenie, że poczynający geometrowie, chociaż doskonali w języku łacińskim snadniej pamiętają, który jest triangut dwuściennorowny niżeli isosceles, który równościenny niżeli scalenum (Solski 1683).

Takie werbalizacje tworzyły przekonanie odbiorców o konieczności zastępowania wyrazów obcych rodzimymi, gdyż te pierwsze utrudniają lekturę.

3. Należy tworzyć rodzime zastępniki zapożyczeń.

Ten aspekt reprezentacji wyrażał konieczność zapobiegania odruchowemu wręcz posługiwaniu się jednostkami obcymi i miał skłaniać do szukania lub tworzenia polskich ekwiwalentów.

Piotr Skarga (1603) w dedykacji Stanisławowi Karnkowskiemu opisał sposób translacji książki Baroniusa — wobec braku polskiej terminologii teologicznej starał się wprowadzać rodzime neologizmy.

Malcher Piotrkowita (1579) podkreślał, że należy przezwyciężać trudności w thumaczeniu terminów medycznych ze względu na potrzebę powstawania polskich książek medycznych. W zakończeniu przedmowy Wawrzyniec z Przasnysza pisał:

To wszytko, iż jest nieco przyszerszym wypisano, proszę, aby nikogo tęsknością czytania nie ruszało, bom to zaprawdę musiał uczynić dla niedostatku słów języka naszego, dla którego jeno słowo łacińskie musi i trzemi języka naszego wyłożyć dla łatwiejszego wyrozumienia (Wawrzyniec z Przasnysza 1559).

Kasper Pętkowski także radził sobie z obcymi jednostkami za pomocą rodzimych ekwiwalentów, choć powodowało to wydłużenie tekstu: „wolałem czasem trudne słowo greckie dwiema i trzema polskiemi wyrazić, żebym tylko sentencją własną ich (autorów) przełożył, niżeli które słówko ująć” (1609). 
W powyższych wypowiedziach implicytnie podkreślano dążenie do zastępowania jednostek obcych rodzimymi — także neologizmami.

\section{Afektywny wymiar reprezentacji społecznej wyrazów zapożyczonych}

W wielu werbalizacjach pojawiał się filtr emocjonalny — autorzy sądów m.in. poprzez ironię, złośliwość, gloryfikację, pochwały starali się oddziaływać na odbiorców, przekonując do wyrazów obcych lub odstręczając od nich. Dominowały w tych opiniach trzy wątki składające się na reprezentację społeczną.

1. Zapożyczenia są lepsze, ładniej brzmią niż rodzime wyrazy.

Ten element reprezentacji wzmacniał dość neutralne przekazy na temat funkcjonalności elementów obcych. Ze względu na wyrazistą pochwałę wyrazów obcych poprzez wykazanie ich walorów funkcjonalnych należy umieścić go w zasobie werbalizacji wartościujących. Jan Januszowski zamieścił obok tekstu polskiego takżełaciński oryginał, aby czytelnik mógł porównać z nim przekład, gdyżze względu na małą zasobność polszczyzny w słowa „gwałt się podczas wykładowi czyni” (1605). Szczególne problemy sprawiało mu tłumaczenie pojęć teologicznych i filozoficznych oraz szeregów synonimicznych, ,a trafiają się i słowa małe, które lepiej podczas po łacinie zostawić niż je po polsku przełożyć" (Januszowski 1605). Wacław Potocki w wierszu „Na toż szósty raz” wspominał o trudnościach w zakresie przekładu wyrazów z łaciny na język polski, zwłaszcza w kontekście ich metaforycznej wartości. Podnosił to w wypowiedzi nacechowanej emocjonalnie: „W polskim wszystkie giną / Kwiatki, które w łacińskim na cały świat słyną" (Potocki 1688: 392-394). W wierszu Na toż siódmy raz autor, pisząc o zasadach przekładu z łaciny, dodał:

Kilką słów sentencyją w łacińskim zawartą / W polskim języku trzeba opisować kartą. / Filozofom dać pokój, gdyż to każdy przyzna, / Że temu nie wydoła uboga polszczyzna (Potocki 1689: 398).

Tego typu sądy i opinie wzmacniały wizerunek zapożyczeń jako elementów lepszych niż rodzime składniki języka. O ile w wypowiedziach przytaczanych nieco wcześniej koncentrowano się raczej na wykazywaniu, że polszczyzna nie oferuje oczekiwanych elementów leksykalnych, o tyle w tym wypadku spośród dwóch konkurujących jednostek — rodzimej i obcej — opowiadano się za wyborem jednostki obcej, dyskredytując w emocjonalnym tonie polską.

2. Panuje moda na zapożyczenia.

Hieronim Wietor dowodził, że Polacy mają szczególny sentyment do obcości w wielu wymiarach, także w języku: „Widzi zaś tego przyczynę jeno w przyrodzeniu polskiem, które ku obcym a postronnym obyczajom, sprawom, ludziom i ję- 
zykom skłonniejsza jest" (1542). O modzie na czeskie słowa i polskim poczuciu niższości wobec „niby” lepiej rozwiniętego i sprawniejszego niż polszczyzna czeskiego przekonywał Łukasz Górnicki:

á czásem drugi/ chocia nie będzie w Czechach/ iedno iż gránicę Śląską przeiedzie/ tho już ináczey nie będzie chciał mowić/ iedno po Czesku/ á Czeszczyzná wie to Bog iáka będzie (Górnicki 1566: 24)

i w kpiącym tonie dodawał:

A jeśli mu rzeczesz, żeby swym językiem mówił: to powiada, iż zapomniał; abo że mu się przyrodzony język prawdziwie gruby widzi: czego dowodząc, wyrwie jakie staropolskie z Bogarodzice słowo, a z Czeskim jakim gładkim słówkiem na sztych je wysadzi, aby swego języka grubość, a obcego piękność pokazać (Górnicki 1566: 25).

Jan Wydżga dodawał łaciny do swego tekstu, gdyż — jak zauważył metaforycznie i zarazem emocjonalnie we wstępie — „teraz weszło w zwyczaj haftować nasz polski język łacińskimi wzorkami” (1662). Aleksander Szwertner thumaczył się czytelnikom w przedmowie do Wytwornych polskich listów z użycia obcych wyrazów tym, że „haftuje polszczyznę łaciną”, ponieważ to „humor i styl wieku” (1692).

Zapożyczanie obcych jednostek przez kolejne wieki objaśniane — zazwyczaj z dużą dozą emocjonalnej krytyki - modą na cudzoziemszczyznę zostało zapoczątkowane właśnie w XVI wieku.

3. Zapożyczenia są niepożądanym lub szkodliwym elementem w polszczyźnie.

Takie przekonanie, werbalizowane zazwyczaj w emocjonalnych passusach, łączone bywało z wydrwieniem makaronizujących rodaków. We fraszce Wielomowny z milczacym Wacław Potocki walczył z makaronizowaniem w dość górnolotnym tonie:

Przedtym jednym językiem, dziś mówią czterema, / Czyż sam polski tyla słów prawdy mówić nie ma, / Że trzeba weń łaciński, francuski i włoski / Mieszać, wstydząc się jawnie wymowy ojcowskiej? / Którzy jednym językiem nie będą przy ręce / To, co sromotne, tracić: oboje dziecięce (Potocki 1688).

Aleksander Smarzewski z ubolewaniem pisał natomiast o posługiwaniu się „cudzymi wyrazami”, które miałyby przyczyniać się do osłabienia lub wręcz zguby polszczyzny. Jednak nie potępiał każdego użycia latynizmów, choć makaronizowanie — już tak:

Nasuwa się na myśl pytanie z Horacego: czyżby ojczysty język był już tak niepłodny, czy raczej nieszczęsny, że nic może kwitnąć bez wyżebranych cudzych wyrazów? Należy nam się obawiać, żeby przez te nadużycia nasz 
język ojczysty nie wyrodził się w jakiś inny, nowy! Dlatego roztropnie należy używać w nim języka łacińskiego, a słów makaronicznych wymyślać nic wolno! (Smarzewski 1700).

W zbiorze wypowiedzi należących do tej części reprezentacji zapożyczeń niebawem zaczną pojawiać się liczniej takie wyrazy, jak: wstyd, hańba, wzgarda i ich ekwiwalenty na określenie samego zjawiska makaronizowania oraz tych, którzy dopuszczają się tego.

\section{Polifazja kognitywna jako podstawa konstruowania reprezentacji społecznej zapożyczeń}

W polu kontekstowym zapożyczeń pojawiały się niejednokrotnie elementy sprzeczne zarówno pod względem argumentacji, jak i eklektycznego łączenia kryteriów wewnętrznojęzykowych i zewnętrznojęzykowych. W TRS takie zjawisko, nazywane polifazją kognitywną, w wieku XVI objawiało się uogólnionym stwierdzeniem: należy walczyć z zapożyczeniami, ale nie ze wszystkimi, trzeba je eliminować, lecz nie w każdej sytuacji.

Jan Malecki w krytycznym komentarzu do Katechizmu... Jana Seklucjana (1545) przeciwstawiał się z latynizmom, akceptował zaś czechizmy (za: Rospond 1948).

Łukasz Górnicki w Dworzaninie polskim wyraził poglądy niektórych rodaków na temat zapożyczeń: niepożądane byłoby zastępowanie wyrazów rodzimych obcymi — sprzeciw wyraził afektywnie jeden z bohaterów dzieła:

Niema sie co podobać, kiedy kto mając swe włosne polskie słowo, zarzuciwszy ono, pożycza na jego miejsce s cudzego języka [...] (Górnicki 1566: 25).

Mimo tej deklaracji dalej pojawiały się wypowiedzi charakterystyczne dla polifazji - wykorzystanie $\mathrm{w}$ tekście zapożyczenia dopuszcza się w pewnych okolicznościach, tu: gdy brakuje rodzimego elementu językowego. Afektywny komentarz „nie ganię tego” wzmocniony został czasownikiem „dozwalam”:

Prawda jest, gdzieby słowa polskiego nie było na tę rzecz, którąby Polak okrzcić miał, abo w przetłumaczaniu z jednego języka na drugi potrzebowałby cudzego słowa, nie telko tego nie ganię, kiedy s tak podobnego naszej mowie języka, jaki jest czeski, weźmie słowo, ale też i z łacińskiego [...] wziąć mu dozwalam (Górnicki 1566: 25).

W końcu bohater Dworzanina... dopuszczał — jak wielu ówczesnych — swobodne posługiwanie się przyswojonymi jednostkami obcymi, najpierw jednak oceniając emocjonalnie tych, którzy chcieliby zastępować rodzime wyrazy łacińskimi: 
A przeto, gdzie jest dobre polskie słowo, tam źle czyni, kto łacińskie miasto niego kładzie; chyba kiedy sie trefi słowo już tak zwyczajne, tak utarte, że je niemal wszyscy rozumieją. Abo też iż włośnie z łacińskiego na polskie przełożone być nie może, bo wtenczas wolę łacińskie, niż polskie, jako to wolę, iż kto rzecze philozoph niż mędrzec, bo to już każdy rozumie, a ktemu nie włośnie to z greckiego Philozophia, mędrość (Górnicki 1566: 25).

Umiarkowane i funkcjonalne posługiwanie się wyrazami zapożyczonymi było do przyjęcia, jednak potępiano nadmierne makaronizowanie - nazywając je pejoratywnie ,wydwarzaniem”. Ten składnik stał się stałym elementem reprezentacji społecznej wyrazów obcych w kolejnych wiekach.

Polifazję jako podstawę sądu można też wskazać m.in. w przedmowie Pobożnemu Czytelnikowi do przekładu Biblii Szymona Budnego (1572). Tłumacz objaśniał, że tekst przekładu jest dosłowny ze względu na rangę dzieła. Wprowadzenie rodzimych zastępników uzasadniał koniecznością jasności tekstu, bronił zapożyczeń słowiańskich, ale oponował przeciw wyrazom niemieckim i włoskim jako potencjalnym składnikom przekładu. W końcu mimo wszystkich tych uwag opowiadał się za czystością polszczyzny, co jednoznacznie stawiało jego wywód w zasobie sądów opartych na polifazji kognitywnej: postępowanie sprzeczne metodologicznie Budny uzasadniał koniecznością opracowania adekwatnego i dobrego przekładu.

W powyższym zbiorze należałoby umieścić także słowa Krzysztofa Opalińskiego. W satyrze Na tych, co się sobie madrymi i uczonymi zdadza afektywnie bronił polszczyzny przed makaronizowaniem i jednocześnie pragmatycznie przekonywał o możliwości odstąpienia od zachowania jej czystości, gdy nie ma odpowiedniego słowa polskiego:

Naśmieszniejsza, gdy owo łacinę mieszają / W polski język i głupie, i źle, i niewcześnie. / Nie pomniąc, że tam tylko łaciny potrzeba / Zażyć, gdzie polskie słowo nie ma tej i takiej / Energijej jak trzeba. U nich to namędrsza Macaronice mówić, a siać solecyzmy / Z barbaryzmami (Opaliński 1650).

W reprezentacji społecznej zapożyczeń takie opinie antycypowały funkcjonalne postrzeganie roli zapożyczeń - deklarowany sprzeciw ogólny przeciw wyrazom obcym łagodzono, gdy w rodzimym języku nie występowały jednostki adekwatne opisowo. Także nie należało domagać się mechanicznego i „co do zasady” eliminowania tych pożyczek, które utrwaliły się i zadomowiły w polszczyźnie.

\section{Zakończenie}

Kształtowanie się reprezentacji społecznej zapożyczeń rozpoczęło się zasadniczo niemal równolegle z wzrostem świadomości językowej w XVI wieku, ujaw- 
niającej się publikowaniem znacznie większej liczby tekstów w języku polskim oraz zwiększeniem jego obecności w przestrzeni publicznej. Coraz częściej autorzy ówczesnych wypowiedzi zwracali uwagę na relację pomiędzy polszczyzną a językami obcymi, pisząc m.in. o zapożyczeniach, ich wadach i zaletach oraz wpływie na rozwój rodzimego języka. W sferze publicznej dochodziło do wymiany opinii, komentowania ich, polemik, w polu semantycznym umieszczano różne argumenty, dowody, sądy, sposoby wartościowania. Wyrazistą sprzeczność w ich wizerunku ilustrowały werbalizacje oparte na polifazji kognitywnej, łączące opinie wyrażane przez skrajnych zwolenników i przeciwników cudzoziemszczyzny.

Na podstawie przeprowadzonych analiz można przedstawić uogólniony zasób podstawowych, znajdujących się w jądrze składników ówczesnej reprezentacji społecznej zapożyczeń.

1. Na oznaczenie jednostek obcych używano licznych nominacji — zarówno bardziej opisowych, jak i nacechowanych emocjonalnie, m.in.: greckie, łacińskie, czeskie, żydowskie słowa, wyrazy bułgarskie; słowa z łacińskiego języka; cudze słowa, słowa zagraniczne/cudzoziemskie, cudzoziemskie/spolszczone terminy; makaronizmy, słowa makaroniczne, barbaryzmy; latynizmy, grecyzmy; język łaciński (tj. wyrazy z tego języka); siła rzeczy słowiańskiej, serbskiej; łacińskie wzorki. Już w samych ekwiwalentach ujawniał się nierzadko stosunek do zapożyczeń.

2. Zasób deskryptywny wypełniły dwa podzbiory uogólnionych werbalizacji — ilustrowały one pozytywny sposób postrzegania zapożyczeń (m.in. ze względu na brak rodzimej terminologii obce wyrazy wypełniały lukę leksykalną $\mathrm{w}$ wielu dziedzinach, ponadto dawały możliwość trafniejszego oddania istoty tekstu podczas przekładu) oraz wyrażały negatywne stanowisko wobec nich (m.in. zapożyczenia są niezrozumiałe i należy je pomijać podczas translacji).

3. Liczniejsze składniki tworzyły zasób emocjonalny reprezentacji społecznej — także dychotomiczny. Na afektywny wymiar składały się werbalizacje ilustrujące pozytywne postrzeganie zapożyczeń (m.in. uznawano je za jednostki lepsze niż rodzime, polskie wyrazy miały gorzej brzmieć niż obce). Częściej kształtowano ich negatywny obraz (m.in. uznawano je za wyrazy modne, ale nie należało ulegać tej modzie; moda na czechizmy kompromitowała Polaków; makaronizowanie było „głupie, złe i niewczesne”, a wplatających nadmiernie obce słowa do rodzimego tekstu należało potępiać; wyrazy obce stanowiły ponadto zagrożenie suwerenności narodu, a posługiwanie się nimi było szkodliwe; polskie neologizmy oceniano jako lepsze niż zapożyczenia, nawet jeśli byłyby dłuższe albo złożone z kilku jednostek; nagminne wtrącanie wyrazów obcych do rodzimego języka było zaś godne pożałowania, a posługiwanie się łaciną to wstyd, hańba).

4. Ujawnił się także znaczący zasób werbalizacji oparty na polifazji kognitywnej: wyrazy obce uznawano za zasadniczo złe, szkodliwe, niepotrzebne, ale nie ze wszystkimi należało walczyć w równym stopniu, niektóre należało zaak- 
ceptować, zwłaszcza te najdawniej do polszczyzny przyjęte i zasymilowane, także słowiańskie oraz niemające rodzimych odpowiedników.

Reprezentacja społeczna zapożyczeń miała więc dwa wyraziste aspekty: deskryptywny — afirmujący funkcjonalne zalety zapożyczeń, wewnątrzjęzykowe, systemowe umocowanie ich bytu, dające racjonalną motywację do ich używania, oraz afektywny — kształtujący postawę niechęci do zapożyczeń i ich używania, motywowany zewnętrznojęzykowymi czynnikami. Oprócz tych ambiwalentnych składników pojawiła się swoista próba ich pogodzenia - ujawniała się ona w uogólnionych wypowiedziach typu: zapożyczenia zasadniczo nie są pożądane, ale czasem nie da się bez nich obejść, są pod pewnymi względami niezbędne, przynajmniej niektóre. Konkurowało $\mathrm{w}$ tych sądach stanowisko afektywne (niechęć) z deskryptywnym (funkcjonalność jednostek), dlatego można mówić o wewnętrznej ich sprzeczności.

W kolejnych wiekach nastąpiła ewolucja reprezentacji wyrazów zapożyczonych, jednak zasadnicze jej składniki — powstałe w epoce średniopolskiej pozostały trwałe aż do współczesności. Uwidaczniają się one m.in. w wypowiedziach internautów podczas wymiany zdań na forach — poniżej zamieszczone zostały eksplikacje nawiązujące do najdawniejszych opinii o modzie na zapożyczenia, braku rodzimych odpowiedników dla wyrazów obcych albo ich ,gorszego" brzmienia, niezrozumiałości wypowiedzi zawierających pożyczki, ale także ilustrujące zjawisko polifazji (,jestem przeciw, ale...”):

(a) Od pewnego czasu zastanawia mnie, w czym leży przyczyna tego, że coraz częściej i gęściej Polacy używają wyrażeń angielskich zamiast polskich, Np. progress, event, czy performer. [...] Czy chodzi o szpan? A może o pokazanie, że ma się wiedzę i jest się otwartym na zachód. Ja nie jestem w 100\% przeciw, w końcu kocham angielski, ale obawiam się, że nasz piękny język polski bardzo na tym traci ${ }^{1}$.

@ Zgadzam się. Słyszy się 'ałtsorsing', 'developmet', 'draft', 'kołcz', głównie w reklamach leków, cud-kremów, w biznesie. A sprawdzić się nie chce albo nie ma często polskiego odpowiednika. No i gotowe: moda na zapożyczenia Straszne to, moim zdaniem. [...] A dlaczego używamy? Szpan? Chęć bycia cool, na czasie?

@ To jest z jednej strony dobre, bo postęp, nowe słowa itp., ale z drugiej strony są też starsi ludzie, którzy angielskiego nie znają i takie wtrącenia w tv czy w radiu po prostu im mieszają i nie rozumieją czasem pełnego przekazu. Mnie osobiście drażnią reklamy w których zamiast słowa „sos” używają już „dip”.

Czasem również nie ma polskich odpowiedników na określenie angielskich słów (chociażby słowo „benchmarking”).

1 Wszystkie cytaty pochodzą ze strony: http://forum.mlingua.pl/archive/index.php/t-29428. html (dostęp: 20 października 2018). Pisownia oryginalna, skróty autora. Pominięto oryginalne pseudonimy uczestników dyskusji. 
Czasami ludzie używają takich zapożyczeń z tego względu, że podobnie skonstruowane/przetłumaczone słowa w naszym ojczystym języku często brzmią sztywno i nienaturalnie. Sam jednak staram się tego nie robić, jestem jak najbardziej za zachowaniem tradycji językowych w obrębie każdego kraju.

\section{Teksty źródłowe}

Budny S., Pobożnemu Czytelnikowi, [w:] Biblia, to jest księgi Starego i Nowego Przymierza, przeł.

S. Budny, Nieśwież 1572, dr. Daniel z Łęczycy.

Górnicki Ł., Dworzanin polski, Kraków 1566, dr. M. Wierzbięta.

Januszowski J., Do łaskawego czytelnika, [w:] J. Bessarion, Rzecz o pochodzeniu Ducha Św., przeł. J. Januszowski, Kraków 1605, Druk. Łazarzowa.

Kromer M., Przedmowa, [w:] O kościele bożym albo Krystusowym, Kraków 1553, dr. Ł. Andrysowic. Malecki J., Defensio verae Translationis corporis catecldsmi in linguam polonicam, rkps.

Opaliński K., Satyry albo przestrogi do naprawy rządu, Amsterdam 1650.

Pętkowski K., Dedykacja Maciejowi Pstrokońskiemu, biskupowi kujawskiemu, [w:] Święty a powszechny sobór we Florencjej odprawiony, przeł. K. Pętkowski, Kraków 1609, dr. M. Lob.

Piotrkowita M., Dedykacja Janowi Kostce, [w:] Przeciw morowemu powietrzu przestroga, b.m.dr., 1579.

Potocki W., Moralia, 1688-1695, [w:] T. Grabowski, J. Łoś „Moralia”, t. 1-3, Kraków 1915-1918.

Potocki W., Ogród, ale nie plewiony, 1670-1695 (rkps. wyd. A. Bruckner Ogród fraszek, Lwów 1907).

Schneeberger Tigurinus A., Przedmowa, [w:] Medicamentorum simplicium catalogus. Apposita sunt etiam stirpium nomina Polonica, Kraków 1556, dr. Ł. Andrysowic.

Seklucjan J., Krytyka językowa i poprawki wypisane na jednym z egzemplarzy dzieła, [w:] J. Malecki, Catechismus 1545, dr. J. Weinreich (omówił S. Rospond, Druki mazurskie XVI w., Olsztyn 1948).

Siennik M., Przedmowa wydawcy, [w:] Lekarstwa doświadczone, Kraków 1564, dr. Ł. Andrysowic.

Skarga P., Dedykacja Stanisławowi Karnkowskiemu, [w:] C. Baronius, Roczne dzieje kościelne, przeł. P. Skarga, Kraków 1603, dr. A. Piotrkowczyk.

Smarzewski A., Respublica eloquentiae Polonae, 1700.

Solski S., Przemowa, [w:] Geometra polski, Kraków 1683, dr. J. i M. Schedlowie.

Szwertner A., Dedykacja polska Karolowi Ernestowi Baurowi, dziedzicowi na Burchfeldzie, oraz polska i niemiecka przedmowa „Do laskawego czytelnika”, [w:] Wytworne polskie listy, Gdańsk 1692, dr. D.F. Rhetus.

Wawrzyniec z Przasnysza, Przedmowa ku czytelnikowi, [w:] Nauka o prawdziwej i o fatszywej pokucie, Królewiec 1559.

Wydżga J.S., Historia abo opisanie wielu poważniejszych rzeczy, które się działy podczas wojny szwedzkiej w Królestwie Polskim, b.m.r. (między 1662 a 1665), b.dr.

Wietor H., Przedmowa, [w:] Erazm z Rotterdamu, Księgi, które zowa język, z łacińskiego na polskie wyłożony, przeł. anonim, Kraków 1542, dr. H. Wietor.

\section{Bibliografia}

Jadacka H. (2004), Zapożyczenia, [w:] Wielki stownik poprawnej polszczyzny PWN, red. A. Markowski, Warszawa, s. 1692-1694.

Klemensiewicz Z. (1974), Historia języka polskiego, Warszawa. 
Mayenowa M.R. (1955), Walka o język w życiu i literaturze staropolskiej, Warszawa.

Morawski K. (1923), Walka o język polski w czasach odrodzenia, Kraków.

Moscovici S. (1984), The Phenomenon of Social Representations, [w:] Social Representations, red.

R. Farr, S. Moscovici, Cambridge, s. 3-69.

Moscovici S. (2000), Social Representations. Explorations in Social Psychology, Cambridge.

Pisarek W. (1991), Zapożyczenie, [w:] Encyklopedia języka polskiego, Wrocław-Warszawa-Kraków, s. $377-378$.

Taszycki W. (1953), Obrońcy języka polskiego. Wiek XV-XVIII, Wrocław.

Zbróg P., Zbróg Z. (2017), Językowe i pozajęzykowe nośniki reprezentacji społecznych, „Respectus Philologicus" 31 (36), s. 70-81.

\section{The beginnings of the shaping of social representations of borrowings in the public sphere}

\section{Summary}

The article presents an initial phase of the process of shaping of social representations of borrowings. The aim was to obtain a view of the way in which participants of the public sphere talked about these elements of language, how they perceived them as well as what common sense image was created on this basis in the communication sphere and how it was modified. The first judgements and opinions on the matter of foreign words appeared around the 16th century and evolved from that moment. The theory of social representations developed by Serge Moscovici was applied as a theoretical and methodological basis of the description. Its research tools allow us to see the way in which societies construct meanings of matters important to them. On the basis of the analysis of the material it was established that from the beginning there were rather antagonistic elements of social representations of borrowings. The functionality of borrowings was noticed. Yet it was postulated that they should be eliminated from texts on account of the necessity to develop the native language, the incomprehensibility of statements as well as the excessive trend of foreignness.

Keywords: social representations, borrowings 